Published in final edited form as:

Curr Opin Organ Transplant. 2008 October ; 13(5): 536-542. doi:10.1097/MOT.0b013e32830fdfc4.

\title{
Cardiac regeneration and stem cell therapy
}

\author{
Joshua M. Hare and Sandra V. Chaparro \\ Cardiovascular Division, University of Miami Miller School of Medicine, Clinical Research \\ Building/Room 1110, Miami, Florida, USA
}

\begin{abstract}
Purpose of review-Significant recent developments have occurred in the field of cardiac regeneration and stem-cell therapy. Understanding the new technological advances in cell therapy will ultimate allow us to achieve a goal of cell-based cardiac repair.
\end{abstract}

Recent findings-We discuss the latest cell-based therapies (including skeletal myoblasts, bone-marrow-derived cells, stem cells), the recent clinical trials in humans and different delivery techniques.

Summary-Ongoing unraveling of the mechanistic and clinical complexities underlying cardiac regeneration will advance the field of regenerative medicine. Substantial progress is being made by the parallel conduct of basic science studies and clinical trials that are incorporating mechanistic evaluations.

\section{Keywords}

cardiac regeneration; cell-based therapies; stem cells

\section{Introduction}

There is tremendous enthusiasm for the concept of cell-based cardiac repair. Therapeutic advances in this area can fulfill major unmet needs including the heart transplant donor shortage and alleviating morbidity and mortality amongst patients with heart damage due to a variety of insults.

Newer cell-based therapies have been intensively study in the last few years due to the potential benefit in patients with acute myocardial injury, stable coronary artery disease and heart failure.

It is increasingly accepted that adult tissues including bone marrow, adipose tissue, and myocardium itself harbor populations of stem cells with the potential to differentiate into cardiomyocytes, endothelial, and vascular smooth muscle cell [1•] but multiple challenges remain in the understanding of the cell signals, the microenviroment and the survival of these cells.

We review some important recent developments in cell-based tissue regeneration.

\footnotetext{
(C) 2008 Wolters Kluwer Health | Lippincott Williams \& Wilkins

Correspondence to Joshua M. Hare, MD, FACC, FAHA, Louis Lemberg, Cardiovascular Division, Interdisciplinary Stem Cell Institute, University of Miami Miller School of Medicine Clinical Research Building/Room 1124, P.O. Box 019132 (C-205), Miami, FL 33101, USA, Tel: +1 305243 1998; JHare@ @med.miami.edu.

There are no conflicts of interests.
} 


\section{Stem cells}

The average left ventricle contains approximately 4 billion cardiomyocytes and the myocyte deficit in infarction-induced heart failure is about one billion cardiomyocytes [2].

For many researchers the idea of addressing this deficit with a cell-based therapeutic approach is highly attractive. Interest in stem-cell-mediated myocardial repair has grown substantially and there is rapidly accumulating clinical and preclinical data supporting this approach.

Stem cells have properties that include plasticity, the ability to transdifferentiate into cells outside their original lineage [3-5], self-renewal, and, in rare cases, fusion with resident cardiomyocytes. Several lines of evidence support the concept that new endogenous or exogenous cells can incorporate and become functional within the heart. In one series of eight hearts from female donors transplanted into male recipients, samples of atrial and ventricular myocardium from the donor heart showed a high number of primitive cells that originated from the recipient, documented by the presence of a $\mathrm{Y}$ chromosome (that is, chimerism). In addition, these cells differentiated and formed new myocytes, coronary arterioles, and capillaries [6]. In addition to observations such as the latter, experimental data from animal models utilizing bone-marrow-derived cells, skeletal myoblasts, and cardiac-derived stem cells demonstrating engraftment and functional recovery of the heart have supported clinical trials testing the clinical efficacy of these approaches. To date, multiple cell types have been tested with mixed results. The totality of evidence suggests that many cell types tested lead to some improvement in cardiac function. This issue coupled with the lack of definitive proof of cell engraftment had increased the popularity of the idea that cell therapy exerts clinical benefits by a paracrine mechanism. The most important issue that has arisen from all of the cell therapeutic approaches is a growing amount of evidence supporting safety of cardiac cell therapy (with the possible exception to this rule being skeletal myoblast cell therapy).

\section{Cell types}

Different types of stem cell and progenitor cells from autologous or allogenic sources have been used for cardiac regeneration. Each cell type has its own profile of advantages and limitations. In the following sections we briefly review each cell type.

\section{Skeletal myoblasts}

Skeletal myoblasts are progenitor cells resident within skeletal muscle that can be isolated by skeletal muscle biopsies and expanded in vitro, making them feasible only in the setting of chronic myocardial dysfunction. These cells were the first to be utilized in clinical trials and case reports. A recent randomized trial did not show significant benefit in patients with ischemic cardiomyopathy [7]. Thus the future of this approach is currently unclear. Attempts are underway to enhance this therapeutic strategy by modifying skeletal myoblasts by genetic approaches.

\section{Bone-marrow-derived cells}

An early and highly influential report of bone marrow cells used to replace cardiac myocytes in a murine model of myocardial infarction (MI) was reported in 2001 [8]. This finding generated excitement and led to clinical trials of autologous bone marrow intracoronary infusions by 2002. The work in the area of autologous bone marrow has now accumulated several major clinical trials. Despite the accumulation of data, a consensus still does not exist regarding this approach. The major unanswered questions are whether autologous bone 
marrow reduces infarct size, increases ejection fraction, and importantly, at a mechanistic level, leads to transfer of cells capable of engraftment and differentiation into cardiac myocytes. Interestingly, subsequent studies performed in the mouse argued against a substantial degree of differentiation of $\mathrm{c}$-kit ${ }^{+}$bone marrow cells, in fact other groups suggest that the differentiation of bone-marrow progenitor cells into cardiomyocytes is a rare event [9].

\section{Endothelial progenitor cells}

One of the earliest insights into the fact that bone marrow harbors nonhematologic precursor cells came from the description of endothelial precursor cells. These cells, identified by the CD34 antigen, are present in bone marrow and can be harvested in the circulation following stimulation with granulocyte colony-stimulating factor (G-CSF). They have the greatest potential for angiogenesis but their availability in the blood decreases with age, and their function decreases with atherosclerosis. Clinical trials support ongoing study of this cell type for patients with ischemic heart disease.

\section{Mesenchymal stem cells}

Mesenchymal stem cells (MSCs) are bone-marrow-derived adult stem cells that have substantial capacity to facilitate cardiac repair following acute MI. They participate in vasculogenesis and myogenesis [10], and are a rich source of growth factors that contribute to cardiac repair by paracrine signaling. In experimental systems, MSCs-treated hearts exhibit an increase in tissue perfusion, a reduction in apoptosis, reduced infarct size, and dramatic improvements in global and regional cardiac function. Importantly, MSCs have several unique advantages including immunoprivilege, easy ability to grow in culture, and the ability to home to areas of tissue injury [11] making them a candidate for off the shelf easy to administer therapy. MSCs have been tested in a phase I trial for patients with acute MI and are currently in phase I/II and phase II trials for heart failure and acute MI.

\section{Resident cardiac stem cells}

Several laboratories have identified resident cardiac precursor cells with the capacity to differentiate into cardiac myocytes and vascular elements. These cells can be identified by cell surface markers such as c-kit and sca-1, by a side-population phenotype (extrusion of Hoechst dye), or the capacity to self-replicate in cell culture. In humans autologous cardiac stem cells can be isolated from surgical or endomyocardial biopsies and clonally expanded in vitro [12]. Clinical trials are being planned with human c-kit ${ }^{+}$cells and with culture expanded cells. The presence of these cells within the heart offers significant opportunity to further insights into disease pathophysiology as well as to test a putative treatment strategy.

\section{Embryonic stem cells}

Embryonic stem cells (ESCs) are derived from the inner mass of the blastocyst and maintain the property of undifferentiated state with the potential to completely regenerate the myocardium [13]. Although the use of ESCs is limited by ethical concerns, inmmunologic incompatibility and the formation of teratomas [14], several recent reports describe the generation of cardiac precursor cells from ESCs providing opportunity to study myocyte development and generating an ideal and novel system for in-vitro testing of myocytes.

\section{Spermatogonial stem cells}

Recent studies have identified pluripotent stem cells in adult mouse testes that have the capacity to differentiate into cardiac cells $[15,16]$. This finding needs confirmation in 
human trials and may allow cell-based therapy without the ethical and immunological problems associated with embryonic stem cells.

\section{Mode of delivery}

To date multiple studies of cell-based therapies have used three routes of administration: intravenous, intracoronary or direct myocardial injection (transepicardial or transendocardial).

Each approach has advantages and disadvantages. The intravenous infusion is simple, with possible systemic benefits but have a low efficacy of delivery to cells to the heart, and filtration by the lungs. Intravenous delivery was used in a phase I study of allogeneic mesenchymal stem cells in patients with first acute MI. The intracoronary infusion approach, widely used in studies of autologous whole bone marrow, allows access to the infarct-related region with a familiar technique but can cause microvascular obstruction. Direct endocardial injection permits access to all territories of the left ventricle with the potential risk for perforation and requires additional equipment. Several experimental catheter delivery systems are currently in testing, including the Noga system and the Biocardia helical injection system. Finally, epicardial injection can be performed at the time of cardiac surgery with spatial accuracy [17].

\section{Clinical trials}

The clinical impact of stem-cell transplantation in the heart is in its early stages, and, to date, no phase III studies are reported. There are several recent reviews and meta-analyses that include data from approximately 1000 patients with acute myocardial infarction (AMI) [18]. These evaluations, on balance, support the efficacy of bone-marrow-derived cell therapy in patients with coronary artery disease. Importantly, also these analyses support modest improvement in cardiac function as well as infarct-size reduction and reverse remodeling. As such these intermediate stage analyses are supportive of further trials powered to test clinical efficacy. An issue of major consideration at the current time is whether to proceed with larger clinical outcome studies using autologous bone marrow or to proceed with cell preparations comprising enriched stem cells or cells modified to enhance survivability, engraftment, or differentiation capacity.

The latest clinical trials are described in Table 1, Figs 1 and 2 [19].

\section{Acute coronary syndromes}

The most important trials in the area of acute coronary syndromes were randomized assessments of intracoronary autologous bone marrow following acute MI. In the BOOST trial, 60 patients with an AMI who had undergone percutaneous coronary intervention (PCI) were randomly assigned to bone-marrow-cell harvest and intracoronary infusion into the infarct-related artery or a control group [20]. The ejection fraction was similar in both groups at baseline post-AMI, and increased 6 months later by approximately $6 \%$. Interestingly, in a follow-up study reporting results at 18 months (5.9 versus 3.1 percentage points) the difference in ejection fraction increase was no longer statistically significant. As this was due to a catch-up phenomenon in the placebo group this suggested that the benefit was limited to acceleration of left ventricular ejection fraction (LVEF) recovery. Importantly, bone-marrow-cell infusion did not increase the risk of adverse clinical events, in-stent restenosis, or proarrhythmia [21].

The REPAIR-AMI trial was a multicenter trial of 204 patients who underwent primary PCI after an ST elevation MI and were randomly assigned to receive an intracoronary infusion of 
autologous mononuclear progenitor cells or a placebo 2-6 days after the AMI. The primary end-point, the absolute increase in LVEF at 4 months, was significantly higher with active therapy (5.5 versus 3.0 percent with placebo) [22]. A landmark study of bone marrow cells in acute coronary syndrome. Importantly, this trial also reported a reduction in the combined end-point of death, recurrent MI, or a heart failure hospitalization (Fig. 3) [23]. These data from the study's data safety monitoring board represent some of the most important findings in the field to date arguing for continuing clinical study of this therapeutic strategy. Replication of this finding in a phase III study would be of major importance.

Two other randomized trials did not report improvements in the LVEF after treatment with intracoronary bone marrow cells.

ASTAMI randomly assigned 100 patients with an AMI undergoing primary PCI to bonemarrow-derived mononuclear-cell infusion or control. Serial imaging with multiple modalities in each patient (echocardiography, nuclear SPECT imaging, and cardiac magnetic resonance imaging) at baseline and at 6 months found no differences in LVEF or infarct size in the two groups [24].

Janssens et al. [25] reported a randomized trial of 66 patients to mononucleated bonemarrow cells or placebo after one-day post-AMI and found no change in the LVEF between the two groups. Importantly, however, this study did report a significant reduction in infarct size using robust cardiac MRI imaging, a finding that is substantiated in the published metaanalyses. Arguably, the finding of infarct size reduction (although not the study's primary end-point) has greater biological significance than an increase in ejection fraction as it is subject to change based on cardiac-loading conditions.

Cytokine mobilization of progenitor cells from bone marrow may promote myocardial neovascularization with relief of ischemia. G-CSF induces mobilization of bone marrow stem cells, therefore various trials sought to evaluate the effect of G-CSF in patients with myocardial ischemia.

The lack of benefit and possible adverse outcomes with G-CSF was described in the MAGIC trial [26] and the REVIVE-2 trial [27]. In contrast, the FIRSTLINE-AMI found an increase in the ejection fraction [28].

A recent meta-analysis of 10 trials using stem-cell mobilization by G-CSF, including 445 patients, concluded that whereas G-CSF is well tolerated and feasible the totality of evidence did not support a beneficial effect of G-CSF in patients with AMI after reperfusion [29].

\section{Ischemic cardiomyopathy}

Stem cells have also been studied in patients with ischemic cardiomyopathy, largely employing direct intramyocardial injections. In this setting most studies are nonrandomized and lack blinding. The potential efficacy was illustrated in a nonrandomized study of 21 patients in which bone-marrow-derived mononuclear cells were injected directly into areas of viable but dysfunctional myocardium. At two months, there was a significant reduction in the area of reversible ischemia (from 15 to $6 \%$ of total myocardium) and a $6 \%$ increase in ejection fraction in the treated patients but not in controls. Electromechanical mapping demonstrated significant mechanical improvement in the injected segments at 4 months [30].

The IACT study had similar findings employing intracoronary infusions of cells. This exercise was a nonblinded observational study of 18 consecutive patients who had history of 
MI and were compared with a control group that did not receive cellular therapy. At 3 months after intracoronary transplantation of autologous bone marrow mononuclear cells, infarct size was reduced by $30 \%$, the ejection fraction increased by $15 \%$, and infarction wall movement velocity increased by $57 \%$. In contrast, there were no significant changes in the control group [31].

\section{Conclusion}

Cell-based therapy for acute and chronic ischemic heart disease is an extremely exciting new therapeutic approach that is in early stages of development. Development of this therapy has proceeded in an orderly and rigorous fashion with appropriate parallel conduct of clinical trials and mechanistic research. As is the case with all therapies at early stage, complete consensus in clinical trials does not exist. The totality of evidence supports safety and provisional efficacy of cell based therapies. Future challenges include optimizing cell type and delivery method. However, some strategies are already poised for phase II to III investigation. The potential impact of cell-based therapy could potentially revolutionize cardiovascular medicine. Importantly, other disease processes including but not limited to Chagas' disease, myocarditis, heart transplant rejection, and immunomodulation, and chemotherapy-induced heart disease are all disorders potentially amenable to cell-based therapy. In addition, in the future biological pacemaking will be achieved by delivering engineered pacemaker cells into normally quiescent myocardium [32]. The combination of tissue-engineering scaffolds with cardiac stem cells may have a role in the repair of the heart as it has been in other organs [33]. The next decade will undoubtedly see a large number of innovative and exciting clinical trails utilizing cell-based approaches for a number of disorders and applications.

\section{Acknowledgments}

The work is supported by NIH grants U54 HL81028, RO1 AG025017, and RO1 HL84275.

\section{References and recommended reading}

Papers of particular interest, published within the annual period of review, have been highlighted as:

- of special interest

•• of outstanding interest

Additional references related to this topic can also be found in the Current World Literature section in this issue (pp. 561-562).

1. Segers VF, Lee RT. Stem-cell therapy for cardiac disease. Nature. 2008; 451:937-942. [PubMed: 18288183] This paper gives a current summary of therapy using stem cells.

2. Murry CE, Reinecke H, Pabon LM. Regeneration gaps: observations on stem cells and cardiac repair. J Am Coll Cardiol. 2006; 47:1777-1785. [PubMed: 16682301]

3. Wagers AJ, Weissman IL. Plasticity of adult stem cells. Cell. 2004; 116:639-648. [PubMed: 15006347]

4. Jiang Y, Jahagirdar BN, Reinhardt RL, et al. Pluripotency of mesenchymal stem cells derived from adult marrow. Nature. 2002; 418:41-49. [PubMed: 12077603]

5. Blanpain C, Horsley V, Fuchs E. Epithelial stem cells: turning over new leaves. Cell. 2007; 128:445-458. [PubMed: 17289566]

6. Quaini F, Urbanek K, Beltrami AP, et al. Chimerism of the transplanted heart. N Engl J Med. 2002; 346:5-15. [PubMed: 11777997] 
7. Menasche P, Alfieri O, Janssens S, et al. The Myoblast Autologous Grafting in Ischemic Cardiomyopathy (MAGIC) trial: first randomized placebo-controlled study of myoblast transplantation. Circulation. 2008; 117:1189-1200. [PubMed: 18285565]

8. Orlic D, Kajstura J, Chimenti S, et al. Bone marrow cells regenerate infarcted myocardium. Nature. 2001; 410:701-705. [PubMed: 11287958]

9. Murry CE, Soonpaa MH, Reinecke H, et al. Haematopoietic stem cells do not transdifferentiate into cardiac myocytes in myocardial infarcts. Nature. 2004; 428:664-668. [PubMed: 15034593]

10. Tang YL, Zhao Q, Zhang YC, et al. Autologous mesenchymal stem cell transplantation induce VEGF and neovascularization in ischemic myocardium. Regul Pept. 2004; 117:3-10. [PubMed: 14687695]

11. Ramos GA, Hare JM. Cardiac cell-based therapy: cell types and mechanisms of actions. Cell Transplant. 2007; 16:951-961. [PubMed: 18293894]

12. Smith RR, Barile L, Cho HC, et al. Regenerative potential of cardiosphere-derived cells expanded from percutaneous endomyocardial biopsy specimens. Circulation. 2007; 115:896-908. [PubMed: 17283259]

13. Leri A, Kajstura J, Anversa P, Frishman WH. Myocardial regeneration and stem cell repair. Curr Probl Cardiol. 2008; 33:91-153. [PubMed: 18243902]

14. Gulati R, Simari RD. Cell therapy for acute myocardial infarction. Med Clin North Am. 2007; 91:769-785. xiii. [PubMed: 17640547]

15. Seandel M, James D, Shmelkov SV, et al. Generation of functional multipotent adult stem cells from GPR125+ germline progenitors. Nature. 2007; 449:346-350. [PubMed: 17882221]

16. Guan K, Nayernia K, Maier LS, et al. Pluripotency of spermatogonial stem cells from adult mouse testis. Nature. 2006; 440:1199-1203. [PubMed: 16565704]

17. Heldman AW, Hare JM. Cell therapy for myocardial infarction: special delivery. J Mol Cell Cardiol. 2008; 44:473-476. [PubMed: 18234211]

18. Burt RK, Loh Y, Pearce W, et al. Clinical applications of blood-derived and marrow-derived stem cells for nonmalignant diseases. JAMA. 2008; 299:925-936. [PubMed: 18314435]

19. Abdel-Latif A, Bolli R, Tleyjeh IM, et al. Adult bone marrow-derived cells for cardiac repair: a systematic review and meta-analysis. Arch Int Med. 2007; 167:989-997. [PubMed: 17533201]

20. Wollert KC, Meyer GP, Lotz J, et al. Intracoronary autologous bone-marrow cell transfer after myocardial infarction: the BOOST randomised controlled clinical trial. Lancet. 2004; 364:141148. [PubMed: 15246726]

21. Meyer GP, Wollert KC, Lotz J, et al. Intracoronary bone marrow cell transfer after myocardial infarction: eighteen months' follow-up data from the randomized, controlled BOOST (BOne marrOw transfer to enhance ST-elevation infarct regeneration) trial. Circulation. 2006; 113:12871294. [PubMed: 16520413]

22. Schachinger V, Erbs S, Elsasser A, et al. Intracoronary bone marrow-derived progenitor cells in acute myocardial infarction. N Engl J Med. 2006; 355:1210-1221. [PubMed: 16990384]

23. Schächinger V, Assmus B, Britten MB, et al. Improved clinical outcome after intracoronary administration of bone-marrow-derived progenitor cells in acute myocardial infarction: final 1year results of the REPAIR-AMI trial. Eur Heart J. 2006; 27:2775-2783. [PubMed: 17098754]

24. Lunde K, Solheim S, Aakhus S, et al. Intracoronary injection of mononuclear bone marrow cells in acute myocardial infarction. N Engl J Med. 2006; 355:1199-1209. [PubMed: 16990383]

25. Janssens S, Dubois C, Bogaert J, et al. Autologous bone marrow-derived stem-cell transfer in patients with ST-segment elevation myocardial infarction: double-blind, randomised controlled trial. Lancet. 2006; 367:113-121. [PubMed: 16413875]

26. Kang HJ, Kim HS, Zhang SY, et al. Effects of intracoronary infusion of peripheral blood stemcells mobilised with granulocyte-colony stimulating factor on left ventricular systolic function and restenosis after coronary stenting in myocardial infarction: the MAGIC cell randomised clinical trial. Lancet. 2004; 363:751-756. [PubMed: 15016484]

27. Zohlnhofer D, Ott I, Mehilli J, et al. Stem cell mobilization by granulocyte colony-stimulating factor in patients with acute myocardial infarction: a randomized controlled trial. JAMA. 2006; 295:1003-1010. [PubMed: 16507801] 
28. Ince H, Petzsch M, Kleine HD, et al. Preservation from left ventricular remodeling by frontintegrated revascularization and stem cell liberation in evolving acute myocardial infarction by use of granulocyte-colony-stimulating factor (FIRSTLINE-AMI). Circulation. 2005; 112:3097-3106. [PubMed: 16275869]

29. Zohlnhofer D, Dibra A, Koppara T, et al. Stem cell mobilization by granulocyte colony-stimulating factor for myocardial recovery after acute myocardial infarction: a meta-analysis. J Am Coll Cardiol. 2008; 51:1429-1437. [PubMed: 18402895]

30. Perin EC, Dohmann HF, Borojevic R, et al. Transendocardial, autologous bone marrow cell transplantation for severe, chronic ischemic heart failure. Circulation. 2003; 107:2294-2302. [PubMed: 12707230]

31. Strauer BE, Brehm M, Zeus T, et al. Regeneration of human infarcted heart muscle by intracoronary autologous bone marrow cell transplantation in chroniccoronary artery disease: the IACT Study. J Am Coll Cardiol. 2005; 46:1651-1658. [PubMed: 16256864]

32. Marban E, Cho HC. Biological pacemakers as a therapy for cardiac arrhythmias. Curr Opin Cardiol. 2008; 23:46-54. [PubMed: 18281827]

33. Chachques JC, Trainini JC, Lago N, et al. Myocardial assistance by grafting a new bioartificial upgraded myocardium (MAGNUM clinical trial): one year follow-up. Cell Transplant. 2007; 16:927-934. [PubMed: 18293891] 


\begin{tabular}{|c|c|c|c|c|c|c|c|c|}
\hline $\begin{array}{l}\text { Study or subcategory } \\
\text { RCTs }\end{array}$ & $N$ & $\begin{array}{l}\text { Treatment, } \\
\text { mean (SD), \% }\end{array}$ & $N$ & $\begin{array}{c}\text { Control } \\
\text { mean (SD), \% }\end{array}$ & $\begin{array}{l}\text { Favors } \\
\text { control }\end{array}$ & $\begin{array}{l}\text { Favors BMC } \\
\text { treatment }\end{array}$ & Weight, \% & $\begin{array}{l}\text { WMD (random), \% } \\
\quad(95 \% \mathrm{Cl})\end{array}$ \\
\hline Assmus et al. ${ }^{14} 2006$ (BMCs) & 28 & $2.90(3.60)$ & 18 & $-1.20(3.00)$ & & & 8.09 & 4.10 (2.18 to 6.02$)$ \\
\hline Assmus et al. ${ }^{14} 2006$ (CPCs) & 26 & $-0.40(2.20)$ & 18 & $-1.20(3.00)$ & & $=$ & 8.33 & $0.80(-0.82$ to 2.42$)$ \\
\hline Chen et al..$^{15} 2004$ & 34 & $18.00(6.71)$ & 35 & $6.00(7.91)$ & & $\rightarrow$ & 6.62 & 12.00 (8.54 to 15.46$)$ \\
\hline Erbs et al..$^{17} 2005$ & 11 & $7.20(11.47)$ & 11 & $0.00(8.97)$ & & $\rightarrow$ & 2.80 & 7.20 (-1.40 to 15.80$)$ \\
\hline Ge et al..$^{18} 2006$ & 10 & $4.80(9.56)$ & 10 & $-1.90(5.85)$ & & $\rightarrow$ & 3.68 & $6.70(-0.25$ to 13.65$)$ \\
\hline Hendrikx et al. ${ }^{19} 2006$ & 10 & $6.10(8.60)$ & 10 & $3.60(9.10)$ & & & 3.21 & 2.50 (-5.26 to 10.26$)$ \\
\hline Janssens et al. ${ }^{20} 2006$ & 33 & $3.40(6.90)$ & 34 & $2.20(7.30)$ & & & 6.68 & $1.20(-2.20$ to 4.60$)$ \\
\hline Kang et al..$^{21} 2006$ (AMI) & 25 & $5.10(9.32)$ & 25 & $-0.10(12.43)$ & & $\rightarrow$ & 4.26 & $5.20(-0.89$ to 11.29$)$ \\
\hline Kang et al..22 2006 (OMI) & 16 & $0.00(12.80)$ & 16 & $0.20(10.61)$ & & & 3.01 & $-0.20(-8.35$ to 7.95$)$ \\
\hline Lunde et al. ${ }^{23} 2006$ & 50 & $1.20(7.50)$ & 50 & $4.30(7.10)$ & & & 7.21 & $-3.10(-5.96$ to -0.24$)$ \\
\hline Meyer et al. ${ }^{24} 2006$ & 30 & $5.90(8.90)$ & 30 & $3.10(9.60)$ & & & 5.43 & 2.80 (-1.88 to 7.48$)$ \\
\hline Ruin et al. ${ }^{27} 2005$ & 9 & $5.96(11.10)$ & 11 & $-3.21(7.18)$ & & $=$ & 2.89 & 9.17 (0.77 to 17.57$)$ \\
\hline Schichinger et al. ${ }^{28} 2006$ & 95 & $5.50(7.30)$ & 92 & $3.00(6.50)$ & & & 8.04 & $2.50(0.52$ to 4.48$)$ \\
\hline Li et al. ${ }^{31} 2006$ & 35 & $7.10(8.00)$ & 35 & $1.60(7.00)$ & & & 6.55 & 5.50 (1.96 to 9.02$)$ \\
\hline Subtotal & 412 & & 395 & & & & 76.79 & 3.64 (1.56 to 5.73$)$ \\
\hline \multicolumn{9}{|c|}{$\begin{array}{l}\text { Test for heterogeneity, } X_{15}^{2}=59.81(P<0.001), f^{2}=78.3 \% \\
\text { Test for overall effect: } Z \stackrel{=}{=} 3.42(P<0.001)\end{array}$} \\
\hline \multicolumn{9}{|l|}{ Cohort studies } \\
\hline Bartunek et al. ${ }^{15} 2005$ & 19 & $7.10(13.44)$ & 16 & $4.30(13.44)$ & & - & 2.68 & 2.80 (-6.08 to 11.68$)$ \\
\hline Katritsis et al. ${ }^{22} 2005$ & 11 & $1.95(7.19)$ & 11 & $1.62(6.93)$ & & & 4.40 & 0.33 (-5.57 to 6.23$)$ \\
\hline Mocini et al. ${ }^{25} 2006$ & 18 & $5.00(7.65)$ & 18 & $1.00(8.51)$ & & & 4.90 & $4.00(-1.29$ to 9.29$)$ \\
\hline Perin et al..$^{26} 2004$ & 11 & $5.10(6.47)$ & 9 & $-3.00(10.12)$ & & $\rightarrow$ & 3.28 & 8.10 (0.46 to 15.74$)$ \\
\hline Strauer et al. ${ }^{29} 2002$ & 10 & $5.00(9.06)$ & 10 & $4.00(7.00)$ & & & 3.59 & $1.00(-6.10$ to 8.10$)$ \\
\hline Strauer et al. ${ }^{30} 2005$ & 18 & $8.00(8.06)$ & 18 & $1.00(10.00)$ & & $\longrightarrow$ & 4.38 & 7.00 (1.07 to 12.93$)$ \\
\hline Subtotal & 87 & & 82 & & & & 23.21 & 3.83 (1.18 to 6.48$)$ \\
\hline \multicolumn{9}{|c|}{$\begin{array}{l}\text { Test for heterogeneity, } X_{5}^{2}=4.32(P=0.51), f^{2}=0 \% \\
\text { Test for overall eEffect: } Z=2.83(P<0.005)\end{array}$} \\
\hline Total & 499 & & 477 & & & & 100 & 3.66 (1.93 to 5.40$)$ \\
\hline \multicolumn{9}{|c|}{$\begin{array}{l}\text { Test for heterogeneity, } X_{19}^{2}=64.73(P<0.001), f^{2}=70.6 \% \\
\text { Test for overall effect: } Z=4.14(P<0.001)\end{array}$} \\
\hline & & & & -10 & $M^{-5}$ rar & $\begin{array}{lcc}0 & 5 & 1 C \\
\operatorname{lom}(95 \% \mathrm{Cl})\end{array}$ & & \\
\hline
\end{tabular}

Figure 1.

Improvements in ejection fraction in patients treated with bone-marrow-derived cells compared with controls

The figure shows the summary of cohort studies and randomized controlled trials (RCTs). Transplantation with BMC resulted in a $3.66 \%$ (95\% CI, 1.93-5.40\%) increase in mean LVEF. AMI, acute myocardial infarction; BMC, bone-marrow-derived cells; CPCs, circulating progenitor cells; OMI, old myocardial infarction; WMD, weighted mean difference. Reproduced with permission from [19]. 


\begin{tabular}{|c|c|c|c|c|c|c|c|c|}
\hline Study or subcategory & $N$ & $\begin{array}{l}\text { Treatment, } \\
\text { mean (SD), \% }\end{array}$ & $N$ & $\begin{array}{c}\text { Control } \\
\text { mean (SD), \% }\end{array}$ & $\begin{array}{r}\text { Favors } \\
\text { BMC treatment }\end{array}$ & $\begin{array}{l}\text { Favors } \\
\text { control }\end{array}$ & Weight, \% & $\begin{array}{l}\text { WMD (random) } \\
\quad \%(95 \% \mathrm{CI})\end{array}$ \\
\hline Chen et al. ${ }^{16} 2004$ & 34 & $-19.00(8.54)$ & 35 & $-5.00(10.00)$ & $\leftarrow$ & & 14.28 & -14.00 (18.38 to -9.62$)$ \\
\hline Erbs et al. ${ }^{17} 2004$ & 11 & $-1.77(9.23)$ & 11 & $-0.93(9.00)$ & & & 10.01 & $-0.84(-8.46$ to 6.78$)$ \\
\hline Janssens et al..20 2006 & 33 & $-8.91(11.73)$ & 34 & $-5.34(11.71)$ & & - & 12.58 & $-3.57(-9.18$ to 2.04$)$ \\
\hline Lunde et al. ${ }^{23} 2006$ & 50 & $-11.00(12.70)$ & 50 & $-7.80(8.70)$ & & & 14.44 & $-3.20(-7.47$ to 1.07$)$ \\
\hline Meyer et al. ${ }^{24} 2006$ & 30 & $-7.00(12.73)$ & 30 & $-5.82(10.51)$ & $\rightarrow$ & & 12.18 & $-1.18(-7.09$ to 4.73$)$ \\
\hline Subtotal & 158 & & 160 & & & & 63.50 & $-4.84(-10.13$ to 0.44$)$ \\
\hline \multicolumn{9}{|c|}{$\begin{array}{l}\text { Test for heterogeneity, } X_{4}^{2}=19.45(P<0.001), f^{2}=79.4 \% \\
\text { Test for overall effect: } Z=1.80(P=0.07)\end{array}$} \\
\hline \multicolumn{9}{|l|}{ Cohort studies } \\
\hline Bartunek et al. ${ }^{15} 2005$ & 19 & $-5.50(17.88)$ & 16 & $-2.40(15.07)$ & $\leftarrow$ & & 6.81 & $-3.10(-14.02$ to 7.82$)$ \\
\hline Perin et al. ${ }^{26} 2004$ & 11 & $-4.40(9.44)$ & 9 & $-2.80(10.74)$ & $\leftarrow$ & & 8.54 & $-1.60(-10.56$ to 7.36$)$ \\
\hline Strauer et al. ${ }^{29} 2002$ & 10 & $-18.00(10.44)$ & 10 & $-5.00(9.62)$ & $\leftarrow$ & & 8.71 & $-13.00(-21.80$ to -4.20$)$ \\
\hline Strauer et al. ${ }^{30} 2005$ & 18 & $-8.00(8.51)$ & 18 & $-1.00(9.00)$ & & & 12.43 & $-7.00(-12.72$ to -1.28$)$ \\
\hline Subtotal & 58 & & 53 & & & & 36.50 & $-6.58(-11.06$ to -2.11$)$ \\
\hline \multicolumn{9}{|c|}{$\begin{array}{l}\text { Test for heterogeneity, } X_{5}^{2}=3.64(P<0.30), f^{2}=17.6 \% \\
\text { Test for overall effect: } Z=2.88(P=0.004)\end{array}$} \\
\hline Total & 216 & & 213 & & & & 100 & $-5.49(-9.10$ to -1.88$)$ \\
\hline \multicolumn{9}{|c|}{$\begin{array}{l}\text { Test for heterogeneity, } X_{5}^{2}=23.23(P<0.003), f^{2}=65.6 \% \\
\text { Test for overall effect: } Z=2.98(P=0.003)\end{array}$} \\
\hline & & & & & $\begin{array}{lr}-10 & -5 \\
\text { WMD rando }\end{array}$ & $\begin{array}{c}5 \\
m(95 \% \mathrm{Cl})\end{array}$ & 10 & \\
\hline
\end{tabular}

Figure 2.

Decrease in mean infarct scar size in patients treated with bone-marrow-derived cells (BMC) compared with controls

The figure shows the summary of cohort studies and randomized controlled trials (RCTs). Transplantation with BMC resulted in a $5.49 \%$ (95\% CI, $-9.10 \%$ to $-1.88 \%$ ) decrease in mean infarct scar size. The overall effect was statistically significant in favor of BMC therapy. WMD indicates weighted mean difference. AMI, acute myocardial infarction; BMC, bone-marrow-derived cells; CPCs, circulating progenitor cells; OMI, old myocardial infarction; WMD, weighted mean difference. Reproduced with permission from [19]. 


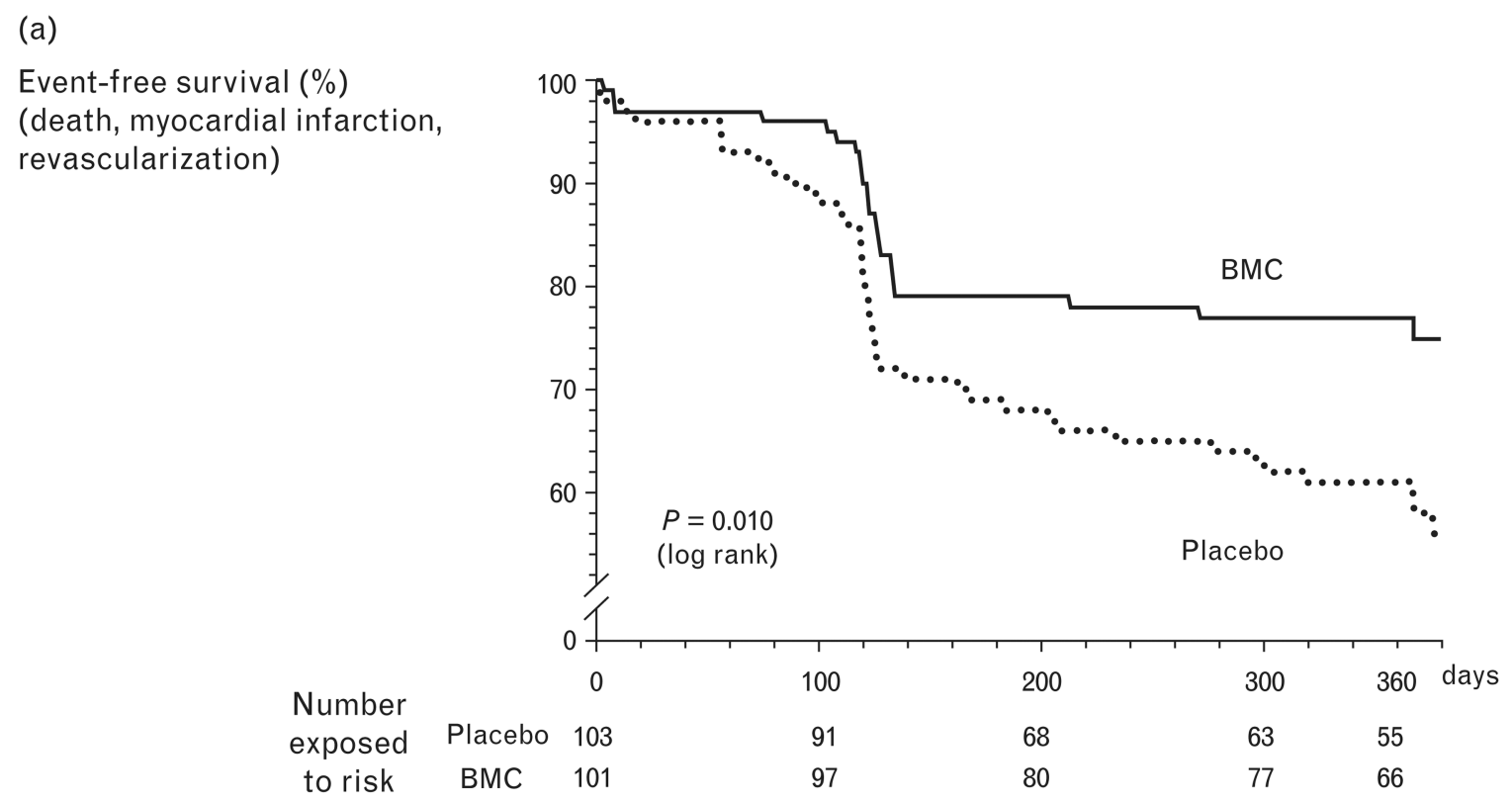

(b)

Event-free survival (\%)

(death, myocardial infarction, rehospitalization for heart failure)
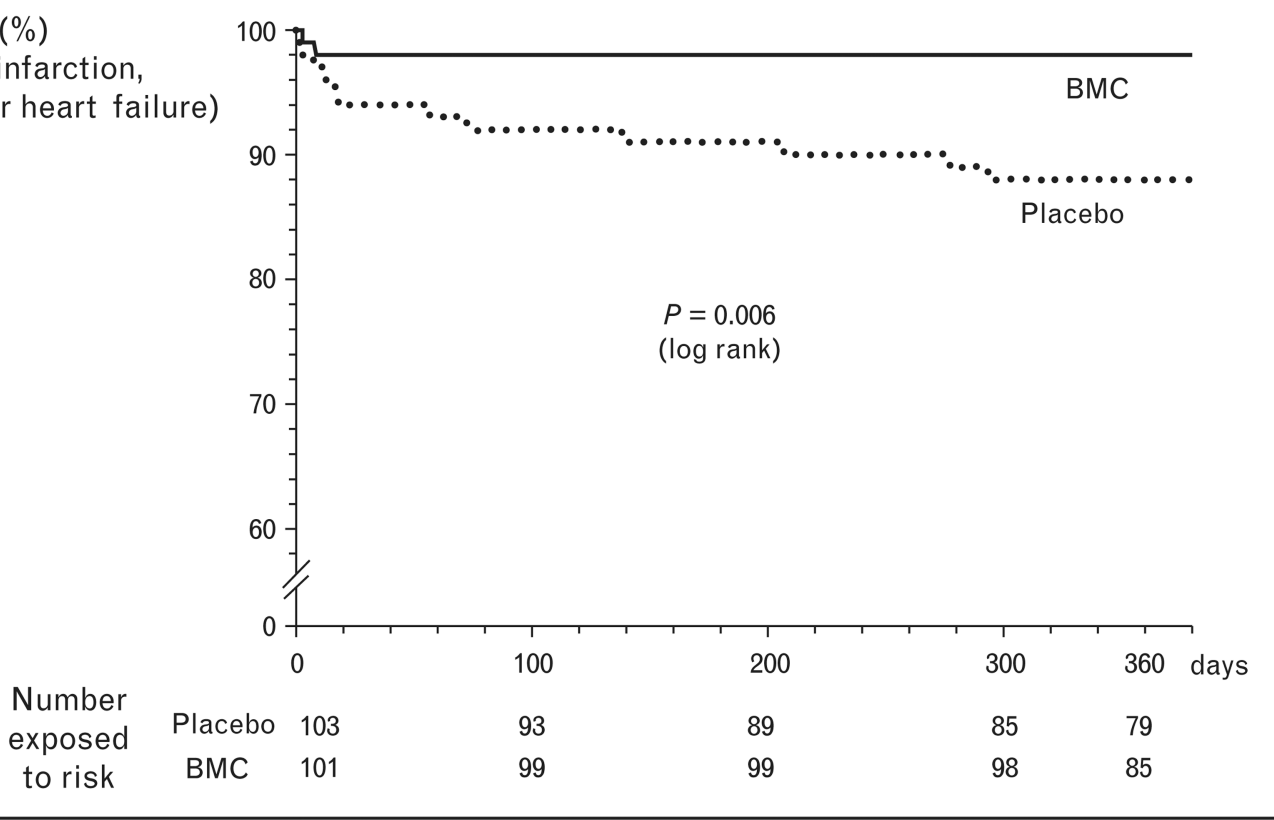

Figure 3.

Kaplan-Meier event-free survival analysis of the REPAIR-AMI trial Comparing (a) death, recurrence of myocardial infarction, or revascularization procedures and (b) death, recurrence of myocardial infarction, or rehospitalization for heart failure among patients treated with bone-marrow-derived cells and placebo. BMC, bone-marrowderived cells. Reproduced with permission from [23]. 
Table 1

Tabulation of latest clinical trials

\begin{tabular}{lccclrcc}
\hline Study & Design & $\boldsymbol{N}$ & Cell type & Delivery & Follow-up (months) & Outcome (EF \%) & $\boldsymbol{P}$ \\
\hline Meluzin 2007 & R-SB & 60 & BMC & Intracoronary & 12 & EF +7 & 0.03 \\
Tatsumi 2007 & NR & 54 & CPC & Intracoronary & 6 & EF +6 & 0.04 \\
Choi 2007 & NR & 73 & CPC & Intracoronary & 6 & EF +2.8 & NS \\
Ahmadi 2007 & NR & 27 & EPC & Intramyocardial & 14 & WMSI & 0.006 \\
Stamm 2007 & NR & 55 & EPC & Intramyocardial & 6 & EF +6.3 & 0.02 \\
Losordo 2007 & R-DB & 24 & EPC & Intramyocardial & 6 & NA & NA \\
Menasche 2008 & R-DB & 97 & SMB & Intramyocardial & 6 & EF -0.3 & 0.95 \\
Hirsch 2008 & NR & 26 & BMC & Intracoronary & 4 & EF +2.2 & 0.03 \\
\hline
\end{tabular}

